\title{
SPECIAL PROBLEMS IN THE LEVY OF MUNICIPAL EXCISE TAXES
}

\author{
Seymour Graubard*
}

Decreasing assessed valuations of realty, new services and the impact of relief needs have made it necessary for municipalities to obtain additional revenues. Traditionally bound to a real estate tax as the chief source of income, the cities have found it necessary during the past decade to experiment with excise taxes. In New York City, for example, the assessed valuations of real estate for tax purposes have dropped nearly four billion dollars, thus resulting in the loss to the city of some Bo millions of dollars in potential taxes within the state constitutional tax limit of two per cent on assessed valuations. The real property tax continues to be the largest source of local revenues but annually shows a small decline in the percentage of the total receipts of municipalities. It is estimated that approximately $x 8$ per cent of the total collections of cities, aside from state grants, now comes from excise taxes, license fees and miscellaneous revenues. ${ }^{1}$

There is no one pattern followed by the cities in imposing excise taxes. The types of taxes used by each local community vary with the particular economic problems of the community and the extent of its powers under the provisions of its state constitution and the acts of its state legislature. The most common of the municipal excises are the sales tax and the gross receipts tax; but it must be borne in mind that a tax of this character may be called a "stamp tax," following the manner of its payment, a "cigarette tax," because of its limited tax base, a "license tax," "utility tax," "amusement tax" or "turnover tax," or there may be employed the variety of names such as are used by the West Virginia cities of Bluefield, Charlestown, Huntington and Morgantown.

These municipal taxes, whatever their designation, present in large measure the same legal and administrative problems as fall upon the states which employ like levies. But because the physical areas of cities are relatively small, and because municipal corporations depend for their powers on their state legislatures, they have certain additional and distinctive problems to face, which it is the purpose of this article to present. Emphasis is given to the experience of New York City, which has pioneered in the imposition of municipal excise taxes and whose leadership has been

- A.B., I93I, LL.B., 1933, Columbia University. Law Secretary to Comptroller, City of New York. Lecturer on New York City Government at New School for Social Research, 1938; at New York University, 1940-194I. Author (with Joseph D. McGoldrick), ADnINisrrative Regulation of Buildings IN NEw YoRK CITY (in press). Contributor to periodicals on subjects of taxation and local government.

${ }^{1}$ Lepawsky, Municipal Revenues (1940) 7 Mun. YeAr Bcox 170, 172. 
followed to some degree by other cities in the nation. ${ }^{2}$ To determine the place that these local taxes should occupy in the over-all tax structure of the nation is beyond the scope of this article, although the issues and facts analyzed have lead to some conclusions which are briefly mentioned. The particular problems to be discussed are: (I) the geographic and economic factors which determine the types and rates of municipal taxes; (2) the legal limitations imposed by the states on the power of cities to levy excise taxes; (3) the extent to which the municipality may tax intrastate activities which originate or conclude outside the taxing municipality; and (4) the advantages and disadvantages of municipal administration of excise taxes.

\section{Economic Factors Determining Types and Rates of Municipal Taxis}

Disregarding internal political pressures, which after all are common to both state and city alike, the one problem emphasized in the consideration of local excises is that of the extent to which the tax will harm the business of the city in intercity competition. The experience of Philadelphia, which in November, 1938, repealed a nine-months old two per cent sales tax, has been described by an assistant solicitor of that city in a way that highlights this issue: 3

In order to understand this situation, it is necessary to realize that immediately across the Delaware River is located the City of Camden, N. J., which is a fairly large industrial city and has a number of shopping centers and that in Delaware County, which adjoins Philadelphia, there is a large settlement known as "The 6gth Street Section" which was originally built up because of the fact that Philadelphia did not permit the showing of moving pictures on Sunday. That Section did and, as a result of the traffic to it, the settlement in the past ten years has grown to such an extent that one large department store has opened a branch there and others are considering doing so. They have reaped a harvest as a result of the trade driven from the City to that section. In addition to this, we are within ninety miles of the great City of New York and on substantial purchases, the amount of tax justifies the trip. As an example, if a woman is desirous of purchasing a fur coat at a price of approximately $\$ 300$ the tax of $\$ 6.00$ which she would have to pay in Philadelphia, would pay the cost of her trip to New York and return, thus giving her the benefit of the greater market which exists in New York City, plus the benefit of all other attractions of a holiday in that city, the expenses, of course, being borne by the merchants of the City of Philadelphia. The experience of the City Solicitor's office in connection with the enforcement of this ordinance has shown that while it is a lucrative tax for the City in its initial stages, the revenue already raised being in excess of $\$ 2,000,000$, it has driven business outside the City to such an extent that the original estimate of a $35 \%$ loss, made by the merchants when they appeared in opposition to the tax, seems conservative. Even if the tax should not be imposed during the next year, the buying habits thus created will be difficult to overcome, so that in the long run, the city will lose as much as it gained.

While this graphic description of Philadelphia's plight must be deemed somewhat exaggerated in its estimates of loss of business, there is no question about the importance of the size and location of the municipality in determining whether to impose a sales tax. Los Angeles, with its population of $x, 500,000$ and its area of $45^{\circ}$

2 For a detailed presentation of New York City's imposition of excise taxes in 1933-1934, sce Baum, Legal Phases of Local Sales Tax (1936) I4 N. Y. U. L. Q. REv. 28; Chanler, Local Taxation for Relief, in McIntire and Rhyne, Municipalities and the Law in Action (1938) 111.

${ }^{3}$ Shapiro, Philadelphia Revenues, in MCINTIRE AND RHYNe, op. cit. supra note 2, at 33-34. 
square miles, is in a better position to levy such a tax than is Philadelphia, whose 2,000,000 residents live within an area of I29 miles; and the merchants of New York City, which has a population of 7,500,000 and 320 square miles of land, can far better afford a sales tax than can the tradesmen of the neighboring City of Hoboken, N. J., whose 50,000 inhabitants are cramped within an area of less than two square miles.

The measure of safety from trade diversion is the distance and ease of communication between the shopping center of the taxing city and those of non-taxing cities. A city large in area may lose business to competing shopping centers, particularly if many of its residents work or live a short distance from the municipal frontiers. In the middle eastern states and the southern portion of New England, only politically maintained boundary lines separate the thickly populated sections of two or more cities, and the residents of one often find it more convenient to make their purchases across the boundary line. Even New York City, with the Hudson River and the Atlantic Ocean along an extensive portion of its perimeter, has found that those of its merchants who were located near adjacent counties had good reason to complain against the effects of the city sales tax. Some of the storekeepers are able to retain their customary business only by absorbing reductions in prices equivalent to the amount of the sales tax.

On the other hand, a city may be small in area and still be able to impose a sales tax, provided that there is no other city near by to serve as a shopping center. Particularly in the west and midwest, where distances are great between cities, the impositon of a sales tax will not result in any considerable diversion of business. The cost in time and money of travelling to another city cannot be made up in savings on sales tax payments.

Diversion is further discouraged in these sections of the country by reason of the fact that the cities exist as the merchandising and manufacturing centers of more or less sparsely settled areas. They provide a variety of goods which the small town or village store is unable to supply. Furthermore, because their merchants do a large volume of business, their prices are generally lower, even with a two or three per cent sales tax added, than are those in the small communities. Finally, the habit of shopping in a metropolitan district, with its concomitant opportunities of visiting places of amusement and of cultural interest, is not easily broken. Despite Philadelphia's experience, it is believed that trade diversion due to the sales tax in New York City amounts to but a small fraction of one per cent of the business done. While the adoption of the compensating use tax has accounted in part for the retention of sales volume, particularly as regards automobile sales, the fact is that the attractiveness of the city's combined variety of shops, department stores and sales agencies has proved a greater lure than the lack of a sales tax in the adjacent communities.

The intercity competitive aspects of the gross business tax differ somewhat from those of the sales tax. Here we deal with an impost, generally amounting to a fraction of one per cent, which in practice must be absorbed by the manufacturer, wholesaler, warehouseman, broker and retailer. The intercity threat in this case varies directly with the rate of the tax, and the penalty for a harsh tax can be the loss of 
manufacturing or marketing enterprises. When in 1933 the City of New York announced plans for imposing a four cent transfer tax on stock and a five per cent tax on the gross income of stock brokers, the New York Stock Exchange leased premises for a new exchange across the Hudson River in New Jersey. The tax was abandoned, for the proposed tax rate was punitive. But when stockbrokers, along with all other brokers in the city, were subsequently taxed at a rate of one-fifth of one per cent of their gross income, few complaints and no threats were heard.

Manufacturers in New York City took in stride the gross receipts tax of one-tenth of one per cent, but certain of them organized to protest the application of the tax to their interstate business, even though the maximum rate applicable to such transactions was one-fifteenth of one per cent. In their petition to the City Comptroller for an adjustment of the tax rate, these manufacturers pointed out that they were engaged in quantity production of low priced garments in a national market, with competition from manufacturers all over the country, and that they often had to work on a two per cent profit margin. So long as the tax was confined to their sales in New York City alone, where they had practically no competition from outsiders, they had no valid objection; but to shoulder them with a tax, which, though small in rate, was high in proportion to their gross profit, they felt put them to a bad competitive disadvantage. The Comptroller granted their petition to the extent of halving the tax rate on interstate sales. However, at no time was there any danger of a wholesale exodus of these manufacturers from the city. The benefits of a skilled labor market, good transportation, access to raw materials and powerfound in all manufacturing centers as to some types of industry-were too great to be surrendered because of the tax.

Where the business taxed is conducted entirely within the area of the taxing city, the rate of the tax may, of course, be increased with little danger of business loss. Thus a retailer, who is dependent for his trade upon the location of his store, cannot run away from a gross business tax without giving up his business. Furthermore, as the rate of gross profit of the retailer is generally greater than that of the manufacturer or wholesaler, he can absorb a higher rate of tax. This principle has been applied in several states. ${ }^{4}$ Public utilities too, retailers of power, light, heat, refrigeration and

\begin{tabular}{|c|c|c|c|}
\hline \multirow[b]{2}{*}{ Taxing Jurisdiction } & \multicolumn{3}{|c|}{ Rate of Tax } \\
\hline & $\begin{array}{c}\text { Retail } \\
\text { Trades }\end{array}$ & Wholesale & Manufacturing \\
\hline & $\%$ & $\%$ & $\%$ \\
\hline 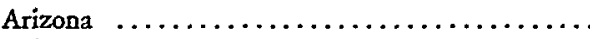 & - 2 & 0.25 & I \\
\hline (n.............. & 0.1 & 0.2 & 0.025 \\
\hline Indiana...... & . I & 0.25 & 0.25 \\
\hline ...................... & . 2 & 0.125 & $0.25-1$ \\
\hline New Mexico $[\ldots, \ldots, \ldots, \ldots, \ldots, \ldots, \ldots$ & . 2 & 0.125 & 0.25 \\
\hline North Carolina $\ldots \ldots \ldots \ldots \ldots \ldots \ldots \ldots \ldots$ & . 3 & 0.05 & - \\
\hline Pennsylvania $\ldots \ldots \ldots \ldots \ldots \ldots \ldots \ldots \ldots \ldots \ldots$ & 0.1 & 0.05 & - \\
\hline (n., & 0.5 & 0.15 & 0.3 \\
\hline
\end{tabular}


transportation on a grand scale, must stand and bear the gross business tax when imposed at a high rate. Originally taxed by New York City in 1933 at a rate of one and one-half per cent of their gross receipts, they had to pay the city three per cent of their revenues in $1934^{5}$ It is manifestly impossible for public utilities to move elsewhere; they therefore provide an economically desirable base for municipal taxes.

\section{Legal Limitations on Municipal Taxing Power}

The Congress, when it imposes a tax, must keep in mind the restrictions of the Federal Constitution, and a state legislature must consider as well the extent of its powers under the state constitution. But the draftsman of a municipal tax has not only to cope with these factors; he must also contend with the fact that while a few state constitutions have been interpreted to hold that a municipality may impose taxes without the need of obtaining particular permission to do so from the legislature, ${ }^{\mathbb{C}}$ the great majority of municipalities must depend for their taxing powers upon a delegation of authority from the state legislatures. ${ }^{7}$ Thus New York's present constitution forbids a municipality to tax without first receiving from the legislature express authorization to collect a specific type of tax in a specified manner. ${ }^{8}$ Even in the small number of states where the greater municipal power obtains, legal identicalness or close similarity of a local and a state tax will cause the former to fall unless the legislature has specifically authorized its imposition in addition to the state tax. ${ }^{9}$ Furthermore, the degree of home rule for municipalities for which most state constitutions provide is paralleled by corresponding restrictions against discriminatory legislative treatment of any one locality or political subdivision. ${ }^{10}$

No general rule may therefore be laid down as to the extent of municipal taxing powers. Each city must be considered sui generis, and the litigant attacking the validity of a municipal excise must look not only to the provisions of the state constitution, but as well to those of the city charter, the enabling act and other statutes which may be applicable. Delegation of taxing powers is commonly effected either through an enabling act or by an amendment to the city's charter. An enabling

\footnotetext{
ENew York State took over this tax in 1937 at a two per cent rate, but permits all cities to tax utilities an additional one per cent. N. Y. Laws 1937 , c. 321, \$2.

${ }^{6}$ West Coast Advertising Co. v. City and County of San Francisco, r4 Cal. (2d) 516, 95 P. (2d) I38 (1939); State ex rel. Zielonka v. Carrel, 99 Ohio St. 220, I24 N. E. I34 (19rg).

I Cooley, Taxation (4th ed. 1924) §I02; 4 Dillon, Muncipal Corporations (5th ed. igri) 51376; McQuillin, Municipal Corporations (2d ed. I936) \$2523; McGoldrick, The Law and Practice of Municipal Home Ruze, 1916-1930 (r933) 340. See also cases cited infra. Note also that a license fee, exacted only to cover the costs of regulating some activity and not for revenue purposes, is not a tax and is generally held to be within the municipality's police powers; see, for example, Jacobs v. Mayor and City Council of Baltimore, I72 Md. 350, r91 Atl. 42x (1937).

${ }^{8}$ N. Y. Const. art. xvi, $\$ x$.

${ }^{\circ}$ See City of Cincinnati v. Amer. Tel. \& Tel. Co., Ir2 Ohio St. 493, I47 N. E. 806 (1925), where a local occupation tax, passed subsequent to a state excise tax based on gross receipts, was held invalid; State ex rel. Greeson v. Roberts, I26 Fla. II4, I7o So. 457 (1936), where a local tax on slot machines, adopted prior to a similar state tax, was held invalid.

${ }_{10}$ McBain, The Law and Practice of Municipal Home Rule (igi6) 48-55.
} 
statute delegates power, as the legislature sees fit, to all cities in the state, to a class of cities or to a single city. ${ }^{11}$ Of course, where the delegation is contained in the charter, the power derived from that instrument is unique to that city, although most municipal charters in each state follow a standard pattern.

The scope of the taxing power delegated will thus vary widely. Before the present New York constitution went into effect in 1938, New York City received the broadest powers possible "to adopt and amend local laws imposing in any such city any tax which the legislature has or would have power and authority to impose."12 But such an enabling act is rare. More common is a qualified grant which either describes the types of taxes that may be levied or which excludes certain activities or properties from taxation. Thus the charters of West Virginia cities authorize them "to license, tax, regulate or prohibit ..." certain activities and businesses "... on which the state does or may exact a license tax." The Pennsylvania Sterling Act, ${ }^{13}$ on the other hand, permits certain cities to levy taxes. on "persons, transactions, occupations, privileges, subjects and personal property . . . except that a city cannot tax privileges, transactions, subjects or occupations or personal property which is now or may hereafter become subject to a state tax or license fee." Both these grants have resulted in considerable litigation. ${ }^{14}$

Certainly, any municipality struggling for additional revenues should take care to obtain as broad a grant of taxing power as possible from the state. The courts view local excise taxes, which are comparative innovations in the economic life of the nation, with a measure of suspicion of the motives, prejudices and common sense of the local councils. But caution in not overreaching is also necessary, lest the enabling act or charter provisions be attacked on the ground that they attempt to delegate to the municipality "the functions of the legislature." Of interest in this regard is the recent case of Mouledoux $v$. Maestri ${ }^{\mathrm{x} 5}$ concerning the validity of a two per cent New Orleans sales tax patterned on the New York City model. By distinguishing between a constitutionally forbidden "surrender of the taxing power vested in the Legislature

${ }^{11}$ For examples of such enabling acts, see N. Y. GeN. Crrx Law \$20-B; N. Y. Laws 1933, c. 815; Pa. Stat. Ann. (Purdon, Supp. 1940) tit. 53, $\$ 46 \mathrm{I}_{3}$ (the Sterling Act).

${ }_{12}$ N. Y. Laws 1933 , c. 815, \$2. Under the present New York constitution, cited note 8, stpra, the legislature is required to "specify the types of taxes" it delegates in the enabling act.

${ }^{13}$ Cited supra note Ir. See also W. Va. Acts Ist Ex. Sess. 1933, c. 33; id. 2 d Ex. Sess. c. 161, 16.

is Compare S. S. Kresge Co. v. City of Bluefield, II7 W. Va. I7, i 83 S. E. 601 (1936), where a one per cent sales tax was held unauthorized, with Mullens v. City of Huntington, II7 W. Va. 740, I 88 S. E. I20 (1936), holding valid a "license tax" based on the gross receipts of retail stores. Compare also People's Natural Gas Co. v. City of Pittsburgh, 317 Pa. 1, 175 Atl. 691 (1934), where a tax on the use of utility meters was rejected on the ground that it was a property tax forbidden under the terms of the Sterling Act, with City and County of Philadelphia v. Samuels, 338 Pa. 32I, I2 A. (2d) 79 (I940), holding that a zo per cent tax on the gross receipts of open parking lots was an excise and not a property tax.

In Ploch v. City of St. Louis, 345 Mo. 1069, 138 S. W. (2d) 1020 (1940), the court stld thar a state sales tax law, enjoining any' city from imposing any levy directly or indircctly on the sale of personal property, did not prohibit a city from adopting an cccupation tax which taxed cigarette merchants on the basis of their gross sales of cigarettes. In City of Pensacola v. Lawrence, 126 Fla. 830, 171 So. 793 (1937), the enabling act provision, authorizing the city to levy license taxes upon any and all occupations and privileges, was deemed not to permit a two per cent tax on the sale of real estate.

152 So. (2d) II (La. I94I). See also N. Y. Steam Corp. v. City of New York, 268 N. Y. 137,197 N. E. I72, 99 A. L. R. II57 (1935). 
by the Sovereign State" and a permissive "delegation by the Legislature of the power to tax," the Louisiana supreme court was able to hold the tax ordinance valid.

\section{Intrastate Transactions Conducted in Part Outside the Taxing Municipality}

A city has the same interstate commerce problems in imposing a sales or gross receipts tax as does a state. But the fact that a city's jurisdiction covers only a fraction of the territory embraced within a state raises the additional issue of the extent to which a city may levy an excise on transactions conducted entirely within the state but partly outside the city's boundaries. Because of the small area of a city, intrastate, intercity sales are common.

In order to avoid multiplicity of taxation of businesses within the state, state legislatures generally include in their enabling acts or city charters limitations restricting the local taxing power to businesses conducted or activities taking place within the corporate limits. Such a provision has been construed by the courts to have somewhat, but not precisely, the verboten effects of the federal interstate commerce clause. Exceptions to this customary solution of the problem are occasionally found. The Alabama Assembly provided by way of an enabling statute that any city or town could fix and "collect licenses for any business, trade or profession done within the police jurisdiction of such city or town and without the corporate limits thereof ..." ; and "police jurisdiction" was defined to cover "all adjoining territory within three miles of the corporate limits." 16 The enabling act for New York City prohibits taxes "on any transaction originating and/or consummated outside of the territorial limits of any such city, notwithstanding that some act be necessarily performed with respect to such transaction within such limits."17 But it further states, ". . provided, however, that nothing herein contained shall limit or prevent the imposition of a tax on gross income or a tax on gross receipts of persons, firms and corporations doing business in any such city."

Despite the broad language of the proviso, the city has not imposed its gross receipts tax on transactions which take place entirely outside the city limits. Thus, if a contracting firm, with its main office in the city, were to build a structure in Albany, and the firm did no work in New York City in connection with that contract, it need not include the receipts from its Albany contract in its tax return. On the other hand, if a manufacturer sells his product to a firm in Albany, the entire proceeds are taxable just as though the transaction were consummated in New York City. This interpretation of the enabling act and of the local tax law has yet to be litigated. Other cities, without such a provision in their enabling act or charter, have also been permitted to levy taxes on the gross receipts of businesses located within the city but engaged in intercity activities. ${ }^{18}$

\footnotetext{
${ }^{10}$ See White v. City of Decatur, 225 Ala. 646, I44 So. 873 (I932), where defendant's place of business was held to be "in adjoining territory," even though separated by a county line and the Tennessee ${ }_{17}$ N. Y. Laws 1934, c. $873, \$ 1$.

${ }^{18}$ See City of Sedalia v. Standard Oil Co. of Indiana, 66 F. (2d) 757 (C. C. A. 8th, r933), cert. denied, 290 U. S. 706 ( 1933 ), where the city was authorized to include as taxable receipts under a license tax on gasoline sellers the proceeds of gasoline sold within the city but delivered' outside; City of Dothan v. Alabama Power Co., 229 Ala. 146, 155 So. 697 (I934), holding that a utility company delivering
} River. 
An entirely different issue is raised in the case of a sales tax or compensating use tax collectible from consumers. In a typical sales tax transaction, a merchant within the taxing locality sells goods to an out-of-town consumer. The transaction takes place within the taxing jurisdiction and hence is theoretically subject to the impost. But practical considerations dictate the city's policy here. The city cannot afford to alienate shoppers from other communities; and, therefore, when delivery of merchandise is made outside its limits, the transaction is considered tax exempt. On the other hand, to give a blanket exemption to all purchasers on their statement that they reside outside the city would encourage tax evasion by residents of the city. Hence, if delivery is made within the city limits, policy dictates that the transaction should be taxable. ${ }^{10}$

Take the reverse situation of a sale made by an out-of-town vendor to a resident of the taxing municipality, where the vendor has no place of business within the taxing jurisdiction. The use tax in New York City attempts to reach this type of transaction in order to prevent the diversion of business from New York City vendors. A New York City resident who purchases materials in Boston is as liable for the two per cent use tax as he would be for the two per cent sales tax had he made his purchase in New York City. But there is a tremendous difference in the administration of the sales and the use tax.

It is far easier for the city to administer the collection of taxes by using vendors as tax collectors than by trying to collect from each purchaser on each purchase made. While most out-of-town purchases by local business firms are reflected on their books and are therefore subject to audit, purchases by individuals for use or consumption in the home can hardly be traced save through an inept, hit-or-miss system of inspecting train and truck deliveries within the municipality, or through an equally inept and even more disagreeable system of espionage. Because of this, it is desirable to bring as many such transactions as possible within the framework of the sales tax and to require the out-of-town vendor to collect the tax for the city.

The means of thus extending the scope of the sales tax were considerably strengthened when the City of New York in McGoldrick v. Berwind-White Coal Mining $\mathrm{Co}^{20}$ succeeded in setting aside certain objections based on the interstate commerce clause of the Constitution. The case held that, regardless of the place of formal "acceptance" of an order, and regardless of the place of technical transfer of title by virtue of an "f. o. b." or similar clause in the contract, the state of delivery

\footnotetext{
within, and only to, one city was "doing business within the city," so as to be subject to an annual license tax, even though the electric energy was generated elsewhere; Bentley-Gray Goods Co. v. City of Tampa, 137 Fla. 64x, 188 So. 758 (1939), where a license tax on wholesale merchants, based on gross sales, was held valid when applied to receipts from merchandise delivered outside the city; Blucfield Produce \& Provision Co. v. City of Bluefield, I20 W. Va. III, I96 S. E. 568 (1938), holding that the municipality could include in its tax base, under a license tax on retailers and wholesalers, receipts from all intrastate, but not interstate, sales.

${ }^{10}$ Where fur coats are purchased in New York City by nonresidents, and the purchase contracts call for temporary storage of the coats within the city and for subsequent delivery out-of-town at the expense of the vendors, the transactions are not subject to the sales tax. Matter of Gunther's Sons v. McGoldrick, 279 N. Y. 148, 18 N. E. (2d) 12 (1938). ${ }^{20} 309$ U. S. 33 (1940).
} 
may require an out-of-state vendor to collect the sales tax on a transaction where the vendor maintained an office within the state of delivery, solicited the order there and shipped the goods there. ${ }^{21}$ This ruling was followed a few months later by that of United Autographic Register Co. v. McGoldrick, ${ }^{22}$ which determined in effect that the enabling act for the city presented no greater obstacles than does the interstate commerce clause to taxing transactions of the Berwind-White type. Although the members of both the Court of Appeals and the Appellate Division divided on the issue, the majority in each court rejected the vendor's contention that the transactions for which tax liability was claimed were consummated outside the City of New York and hence fell within the enabling act's proscription on "the imposition of a tax on any transaction originating and/or consummated outside the [city's] territorial limits...."

The ground of decision is, it is true, superficially reminiscent of the Wiloil era in the federal-state realm:23 "The required approval [from the home office] is really automatic as the instances of rejection of any order are very few, indeed no specific instance was adduced at the hearing. The procedure of approval and acknowledgment is really collateral and incidental. The delivery from the particular source selected by the petitioner outside the State is solely a matter of convenience or economy in the petitioner's method of conducting business."24 Nevertheless, there is little reason to believe that the New York courts intended to tie city power under the enabling act to the now outmoded Wiloil dialectic concerning intent and title, leaving power commensurate with the Berwind-White philosophy of physical delivery to the vicissitudes of further litigation. That battle will not have to be refought on another front. And of course, what holds for the interpretation of the enabling act in regard to transactions involving shipment across state lines, holds a fortiori for transactions involving intrastate shipments across city lines. The vendor who regularly does business with residents of a taxing city will in the future find himself increasingly obligated to act as tax collector for that governmental unit even though he ships his merchandise from other municipalities.

\section{Municipal Tax Administration}

It has been stated of municipal excises: "The local units hold the least desirable position in the total tax system. Limited in area and jurisdictional powers, they cannot well administer sales, gasoline, income, inheritance, and other taxes." ${ }^{25}$ But

${ }^{21}$ Extension of the scope of state and municipal sales taxation on the interstate plane is fully discussed by McNamara, Jurisdictional and Interstate Commerce Problems in Imposition of Excises on Sales, supra this issue. New York City, as a hub of interstate commerce, makes a special effort not to saddle firms which are located outside the city but which do business within it, with burdens that are not borne by all local taxpayers. Thus, where an outside business firm requests that the City Comptroller conduct a tax audit outside the city, the request is generally granted. In such a case the travelling and hotel expenses of the auditors are paid by the taxpayer, but close supervision of such expenses by the tax administrator keeps them to a minimum.

${ }_{22} 260$ App. Div. I57, 2 I N. Y. S. (2d) 129, affd, by memorandum decision, 32 N. E. (2d) 826 (N. Y. r 94 I). ${ }_{23}$ Wiloil Corp. v. Pennsylvania, 294 U. S. 169 (x935).

24 United Automatic Register Co. v. McGoldrick, sttpra note 22, at I6I, 21 N. Y. S. (2d) at 132.

${ }^{25}$ Hillhouse, New Sources of Municipal Revenue (Municipal Finance Officers' Ass'n of U. S. and Canada, 1935) 2. 
even as the small area of a municipality's taxing jurisdiction may work to its economic disadvantage, so does its concentration of taxpayers make the work of administration easier and more economical. Disadvantages in enforcement are few and may be summarized as follows:

\section{Organization of Tax Enforcement Agency}

The states have had long experience in collecting excise taxes. Through their tax bureaus, with jurisdiction over corporation franchise, income and other taxes, they find it easy to absorb the administration of new imposts into existing organizations. On the other hand, a city cannot rely upon its real property tax bureau to collect a sales or gross receipts tax. An entirely new mechanism is required to deal with a completely different tax base. To some extent a city may overcome this initial disadvantage by importing experienced directors from other jurisdictions; but local demands, particularly in times of economic stress, generally hold such practice to a minimum.

\section{Compensating Use Tax Administration}

The small area of a city makes it inevitable that a larger portion of goods consumed or used within the city should be purchased outside its jurisdiction than is the case with a state. Until such time as a federal sales tax is adopted, it will be impossible for either a state or a city to achieve a high degree of enforcement. While the problem is more serious for a city than a state, its importance will decrease correspondingly as the sales tax is extended to cover intercity and interstate transactions. ${ }^{26}$

Against these disadvantages are several advantages of municipal enforcement.

\section{Registration of Taxpayers}

In determining who should register as a taxpayer or who should file a tax return, a municipality can send a squad of investigators through its streets and buildings to list every businessman who is a potential taxpayer. This the states can do too; but the magnitude of the task in covering rural as well as urban areas precludes a thorough search. Not only is there this difference; a city can minimize the cost by utilizing in the registration its policemen, firemen and other employees. New York City, when it first imposed its sales and gross business taxes, turned the task of registration over to its Police Department, a large portion of whose staff of 18,000 men first distributed registration certificates and then inspected business premises to determine compliance with the requirement that the certificate be hung on the wall. The Police Department is still available to make recurrent checks to see that new businesses are registered. .

Furthermore, several score types of business are licensed by the city for purposes of regulation. The Police Department, Fire Department, License Department, Department of Housing and Buildings, and other agencies supply the names of such

\footnotetext{
${ }^{26}$ See pp. 620-62I, stipra.
} 
concerns to the Emergency Revenue Division and will suspend or revoke licenses or permits of firms which violate the tax laws. The states, supplying only a fraction of the services performed by municipalities, have fewer agencies and fewer men to call upon for such assistance.

Auditing Books of Taxpayers

Auditing work is done more expeditiously where little travelling time is required. Taxpayers may be asked to submit their books for examination at the office of the tax agency without much inconvenience to them. With all tax returns coming from one city, even though neighborhoods vary greatly in character, a norm can be set up for each type of business. Examination of returns against the norm provides a good basis for selecting taxpayers to be audited.

\section{Hearings on Tax Audits or on Regulations}

With the main office of the tax agency in the same city, a taxpayer finds it considerably less expensive to contest assessments made by the agency's auditors and tax counsel. By the same token, taxpayers who cannot afford to go to the state capitol for hearings on tax regulations, will request the administrative officer in charge to hold a hearing to correct inequities in the rules and regulations of the department. The cooperation between the Comptroller of New York City and business groups in holding such hearings accounts in large measure for the city's record on refunds. During the period October I, I934, to December 3r, x940, New York City refunded only $\$ 621,000$ of some $\$ 432,000,000$ collected in excise taxes.

For these reasons the cost of administration in New York City compares favorably with the cost incurred by the states which impose similar taxes. ${ }^{27}$ As no two states or cities impose precisely the same taxes, one cannot generalize on comparative costs of enforcement; but, once a municipality has achieved a measure of experience in enforcement of excises, it should be able to make its collections more efficiently and at lower costs than can the states.

\section{Conclusion}

From the point of view of the national economy and the ideal tax system, municipal excise taxes are undeniably bad. If all the 16,000 taxing jurisdictions in the United States ${ }^{28}$ were to impose their own excise taxes, the admittedly undesirable situation now existing with regard to interstate trade barriers would be aggravated many times over. But we are faced with the hard fact that it is essential that municipal services, which affect the public to a much greater extent than do those of the state and federal governments, should not be impaired, and should continue to expand in accordance with the higher standards that progress brings to all com-

\footnotetext{
${ }^{27}$ Sec Jacoby, Retall Sales Taxation ( $x 938$ ) 29r-292. On state collection costs, see Huston and Berryman, Collection and Enforcement of State Consumption Excise Taxes, supra this issue. The ratio of administrative costs to collections for New York City for the fiscal year ended June 30, 1939, was 1.69 per cent and for the comparable period in $1938,1.68$ per cent.

${ }^{28}$ Ill. Tax Comm., Atlas of Taxing Units, I Survey of Local Finance (1939).
} 
munities. To deprive the cities of taxing powers without adding commensurately to their revenues is to solve in part the trade barrier issue at the expense of the more vital needs of the public. For example, New York City could not have cared for its needy, nor could the cities of New York State now embark on a low cost housing program, without adequate tax resources. Many municipalities during the past decade, in the absence of such resources, were unable to pay the salaries of employees, and had to close schools and curtail other functions. Faced with the necessity of finding new sources of revenue, New York City at one time considered, as against the imposition of its two per cent sales tax, an increase in the subway fare from five cents to seven cents. Only slight research was needed to show that the burden of a higher subway fare would have a more adverse effect upon the poorest people of the city than would sales taxation.

One solution to the problems both of tariff barriers and of additional revenues for localities would be the extension of excise taxes to state areas or possibly the entire nation, and the allocation of the revenues resulting therefrom to those local governmental units most in need.29 However, disparity of need for such revenues among different localities and different states stands in the way of such a plan. ${ }^{30}$ Some businessmen, who now enjoy the advantages of location in a comparatively tax-free community, would oppose, of course, a uniform tax system that would hit them equally with their competitors. But if the present trend continues, it is only a matter of time before the diffculties of doing interstate or even intercity business become so great that practically all businessmen will favor uniformity. At such time we may expect the legislatures and the Congress to cooperate in putting the excise tax system on a better basis.

The advantages of local administration of taxes need not be lost under a system of state-wide or federal tax levies. With a substantial portion of the tax moneys from each locality being returned for local use, the various municipal agencies could be utilized to tighten collections. Decentralization of hearings on audits is possible with resultant economies to taxpayers, and decentralization of hearings on regulations would enable trade associations to cooperate with government even to the extent of policing transactions in order to have all similarly situated businessmen compete on the same basis. Finally, it should be possible under such a system to work out a series of regulations which could be applied locally to fit peculiar community conditions without disrupting the state-wide or national features of such taxes.

\footnotetext{
${ }^{29}$ See LaGuardia, A Uniform System of Taxation, N. Y. Times, Jan. I2, 1940, reprinted in (1940) I8 Taxes 135; Hellerstein and Hennefeld, State Taxation in a National Economy (194I) 54 Harv. L. Rev. 949.

${ }^{30}$ On the problems raised by efforts at geographical allocation, see Smart and Hart, The Distribution of Reventus from State-Collected Constumer Taxes, stupra this issue.
} 